\title{
The effect of cryptorchidism and subsequent orchidopexy on testicular function in adult rats*
}

\author{
B. Jégou†, A. O. Laws and D. M. de Kretser \\ Department of Anatomy, Monash University, Melbourne, Victoria 3168, Australia
}

\begin{abstract}
Summary. Cryptorchidism for 28 or 10 days resulted in a severe disruption of spermatogenesis (assessed histologically or by fertility tests), Sertoli cell function (assessed by seminiferous tubule fluid production after efferent duct ligation, ABP levels, binding of ${ }^{125}$ I-labelled FSH to testis homogenates and serum FSH levels) and Leydig cell function (assessed by serum LH and testosterone levels, in-vitro testosterone production, binding of ${ }^{125} \mathrm{I}$-labelled $\mathrm{hCG}$ ). Orchidopexy after 28 days of cryptorchidism resulted in a poor recovery of spermatogenesis since the majority of tubules were lined by Sertoli cells and a few spermatogonia. No recovery occurred in the indicators of Sertoli and Leydig cell function.

Orchidopexy after 10 days of cryptorchidism also resulted in a poor recovery of spermatogenesis, with a few animals showing partial recovery after 6 months. No recovery occurred in seminiferous tubule fluid production but partial recovery occurred in ABP content and production rate. Serum FSH, LH levels and in-vitro testosterone production by the testis remained elevated and did not change from the values found during cryptorchidism.

Fertility testing at 6 months revealed a small number of rats in which fertility was restored although the number of embryos was lower than in controls. In this group of animals there was a significant improvement in a number of indicators of Sertoli cell and Leydig cell function. These data provide further evidence to link the changes in Sertoli cell and Leydig cell function to the germ cell complement present in the testis.
\end{abstract}

\section{Introduction}

It is well established that cryptorchidism induced by surgery in rats results in disruption of spermatogenesis (Moore, 1924; Nelson, 1951). However, more recent studies have shown that in addition to germ cell damage the function of the Sertoli cells and Leydig cells is disrupted (Hagenäs \& Ritzén, 1976; Kerr, Rich \& de Kretser, 1979a, b; de Kretser, Sharpe \& Swanston, 1979; Jégou, Risbridger \& de Kretser 1983). After the induction of unilateral cryptorchidism, the alterations in Leydig cell function, which consisted of hypertrophy and hyper-responsiveness to hCG stimulation in vitro and in vivo, were confined to the abdominal testis (Risbridger, Kerr \& de Kretser, 1981a; Risbridger, Kerr, Peake, Rich \& de Kretser, 1981c). From these data and those obtained following unilateral efferent duct ligation, it was postulated that (1) the Leydig cells were exposed to controlling factors from the seminiferous tubules and (2) after damage to tubule function, the altered balance caused Leydig cell hypertrophy and hyper-responsiveness (Risbridger, Kerr, Peake \& de Kretser, 1981b; de Kretser, 1982).

$\dagger$ Present address: Faculté des Sciences, Biologie de la Reproduction, Avenue du General Leclerc, 35042 Rennes Cedex, France.

* Reprint requests to Dr D. M. de Kretser. 
This hypothesis was tested by causing seminiferous tubule damage by inducing cryptorchidism and then reversing the spermatogenic damage by performing orchidopexy as described by Nelson (1951). Spermatogenesis and Sertoli cell and Leydig cell function were monitored to establish whether all of the changes were reversible and to determine their temporal relationships.

\section{Materials and Methods}

\section{Surgical procedures}

Cryptorchidism and orchidopexy. Cryptorchidism was induced in 90-day-old Sprague-Dawley rats under ether anaesthesia by translocating the testes into the abdomen through the inguinal ring. The testes were attached to the dorsolateral abdominal wall by a suture passing through the connective tissue capsule of the epididymis. In Exp. 1 orchidopexy was performed after 28 days of cryptorchidism by cutting the suture which held the testis and epididymis in the abdomen. The testes were replaced in the scrotum via the inguinal canals and secured to the base by a suture. The rats were then allowed to recover for 28 or 56 days after orchidopexy. Since recovery of spermatogenesis was poor after 28 days of cryptorchidism (see 'Results'), in Exp. 2 orchidopexy was performed after 10 days of cryptorchidism and the rats were allowed to recover for periods ranging up to 6 months. Control groups of rats were sham-operated at the times of induction of cryptorchidism and orchidopexy.

Measurement of seminiferous tubule fluid production. Unilateral efferent duct ligation was performed according to the technique of Smith (1962). After $16 \mathrm{~h}$, the rats were killed and fluid production was measured as the difference in testis weight between the ligated and unligated testes as described previously (Jégou et al., 1983). The androgen-binding protein (ABP) content of the ligated and unligated testes was measured as described later, the difference between the two providing an index of ABP production over $16 \mathrm{~h}$ (Hagenäs \& Ritzén 1976; Jégou et al., 1983).

\section{Collection and preparation of tissue}

Groups of operated and control animals were killed by decapitation and blood was collected; after being allowed to clot the serum was stored at $-20^{\circ} \mathrm{C}$. The testes and epididymides were dissected out and weighed before being processed for the following measurements:

Histology. Testes used for cytology were fixed in Bouin's solution, embedded in paraffin wax and sectioned at $5 \mu \mathrm{m}$. After haematoxylin and eosin staining the sections were examined by light microscopy.

Binding of ${ }^{125}$ I-labelled $h C G$ and ${ }^{125}$ I-labelled FSH. In Exp. 3 (see below) the testes were decapsulated and homogenized with 4 volumes of Tris- $\mathrm{HCl}$ buffer ( $\mathrm{pH} \mathrm{7.4)} \mathrm{containing} 1$ mMEDTA, $2 \mathrm{~mm}$-mercaptoethanol and $10 \%(\mathrm{v} / \mathrm{v})$ glycerol. After centrifugation at $105000 \mathrm{~g}$ for $1 \mathrm{~h}$ the supernatant was removed and stored for ABP measurements. The pellets were resuspended in $1 \mathrm{ml}$ Tris- $\mathrm{HCl}$ buffer ( $\mathrm{pH} \mathrm{7.4)} \mathrm{containing} 10 \mathrm{mM}-\mathrm{MgCl}_{2}$ and $0.1 \%$ bovine serum albumin and stored at $-20^{\circ} \mathrm{C}$ until assayed.

Measurement of ABP. ABP was measured in the $105000 \mathrm{~g}$ cytosols of the testis and epididymis using steady-state polyacrylamide gel electrophoresis as previously described (Ritzén, French, Weddington, Nayfeh \& Hansson, 1974). The results are expressed as the ABP content per organ.

In-vitro production of testosterone. After decapsulation the testes were washed for a few seconds in $2 \mathrm{ml} \mathrm{Krebs-Ringer-bicarbonate} \mathrm{buffer} \mathrm{(} \mathrm{pH} \mathrm{7.4)}$ containing glucose (1 mg/ml) (KRBG; for composition see Sharpe \& Fraser, 1980). The testes were gently placed on filter paper to remove the excess buffer and then rapidly transferred to a prepared glass vial containing $2 \mathrm{ml} \mathrm{KRBG}$. One of each pair of testes served to provide the basal testosterone production and the other was stimulated by including hCG (Pregnyl, Organon) at a dose of $700 \mathrm{mi} . \mathrm{u} . / \mathrm{ml}$ in the KRBG. This dose has previously been shown to result in maximal stimulation of control and cryptorchid testes 
(Risbridger et al., 1981a). The vials containing the testes were placed in a shaking water bath at $37^{\circ} \mathrm{C}$ for $4 \mathrm{~h}$. The media were then centrifuged for $20 \mathrm{~min}$ at $1500 \mathrm{~g}$ and stored at $-20^{\circ} \mathrm{C}$ until assayed for testosterone.

\section{Radioimmunoassay}

Testosterone. Serum for testosterone measurement was extracted with ether and assayed using a radioimmunoassay whose characteristics have been described previously (Risbridger, Robertson \& de Kretser, 1982). The antiserum was raised against testosterone-3-carboxymethyloxime conjugated to bovine serum albumin and showed $98 \%$ cross-reactivity with dihydrotestosterone. The intra-assay and inter-assay coefficients of variation were $6.8 \%$ and $16 \%$. Media from the invitro testis incubations were assayed directly in the radioimmunoassay.

Serum FSH and $\mathrm{LH}$. Serum was assayed by specific double-antibody radioimmunoassays as previously described (Lee, de Kretser, Hudson \& Wang, 1975). Purified rat FSH (NIAMDD-rat FSH- ${ }_{3}$ ) and rat $\mathrm{LH}$ (NIAMDD-rat $\mathrm{LH}-\mathrm{I}_{6}$ ) preparations were iodinated with ${ }^{125} \mathrm{I}$ and used as tracers. Levels of FSH and $\mathrm{LH}$ were expressed in terms of NIAMDD-rat-FSH-RP1 and NIAMDD-rat-LH-I ${ }_{5}$ respectively. All samples from the experiment were run within a single assay and the within-assay variation ranged from $4 \cdot 0$ to $7 \cdot 8 \%$ for both assays.

\section{Fertility testing}

At each time interval rats selected randomly from the control and experimental groups were used for fertility testing. Each rat (from groups of 5) were caged with 2 females for 8 days and then separated. The females were killed 10 days later and the number of implantation sites in the uteri was determined.

After the 109-day post-orchidopexy group were tested, the remaining rats from this experiment were left until 180 days after orchidopexy. On the basis of the results of the fertility test, the rats were distinguished as fertile or infertile. These rats and the controls, which had also had their fertility tested, were killed and the tissues treated as above.

\section{Statistical analyses}

The results of experiments are expressed as the mean \pm s.e.m. Statistical significance of the results was determined by use of Student's $t$ test or Duncan's Multiple Range test after analysis of variance.

\section{Results}

\section{Experiment 1: orchidopexy after 4 weeks of cryptorchidism}

Recovery of spermatogenesis was poor. After 4 weeks of cryptorchidism, the testicular and epididymal weights were reduced to $35 \%$ and $52 \%$ of control values respectively (Table 1 ). A slight increase in testis weight was noted 4 weeks after orchidopexy but it did not increase further with time (Table 1). There was no increase in epididymal weight after orchidopexy.

In the 4-week cryptorchid rats the seminiferous tubules were reduced in diameter and lined by Sertoli cells with only a few spermatogonia being evident. The Leydig cells formed prominent clumps in the intertubular areas. In the rats allowed to recover for 56 days, the majority of the seminiferous tubules were lined by Sertoli cells and a few spermatogonia. A few tubules showed evidence of recovery with mature spermatids being found at the luminal edge of the seminiferous epithelium. 
Table 1. The effect of 4 weeks of cryptorchidism and subsequent orchidopexy in adult rat on the weight of each testis and epididymis

\begin{tabular}{|c|c|c|c|c|c|}
\hline & \multirow[b]{2}{*}{ Days } & \multicolumn{2}{|c|}{ Testicular wt (g) } & \multicolumn{2}{|c|}{ Epididymal wt (g) } \\
\hline & & Control & Operated & Control & Operated \\
\hline Cryptorchidism & 28 & $1 \cdot 51 \pm \frac{0.04}{(5)}$ & $0.53 \underset{(5)}{ \pm 0.03 *}$ & $0.52 \pm 0.02$ & $0 \cdot 27 \pm 0.02^{*}$ \\
\hline \multirow[t]{2}{*}{ Orchidopexy } & 28 & $\begin{array}{c}1 \cdot 74 \pm 0 \cdot 04 \\
(10)\end{array}$ & $\begin{array}{c}0.84 \pm 0.04 * \dagger \\
(10)\end{array}$ & $\begin{array}{c}0.58 \pm 0 \cdot 01 \\
(10)\end{array}$ & $\begin{array}{c}0.33 \pm 0.01^{*} \\
(10)\end{array}$ \\
\hline & 56 & $\begin{array}{c}1.69 \pm 0.02 \\
(10)\end{array}$ & $\begin{array}{c}0.82 \pm 0.02 * t \\
(10)\end{array}$ & $\begin{array}{c}0.64 \pm 0.01 \\
(10)\end{array}$ & $0.34 \underset{(8)}{ \pm 0.01^{*}}$ \\
\hline
\end{tabular}

Values are mean \pm s.e.m. for the no. of observations in parentheses.

* $P<0.001$ compared $(t$ test) with corresponding control.

$\dagger P<0.01$ compared (Duncan's test) to the value for operated animals after 28 days of cryptorchidism.

Measurement of fluid production and ABP content were all reduced after 4 weeks of cryptorchidism (results not shown) and were similar to the changes noted after 10 days of cryptorchidism (see below). Binding of ${ }^{125}$ I-labelled hCG was reduced and the Leydig cells were

Table 2. The effect of 10 days of cryptorchidism and subsequent orchidopexy on testicular weight, epididymal weight, tubule fluid production, serum testosterone and in-vitro testosterone production

\begin{tabular}{|c|c|c|c|c|c|}
\hline & \multirow{2}{*}{$\begin{array}{l}\text { Cryptorchidism } \\
\text { (10 days) }\end{array}$} & \multicolumn{4}{|c|}{ Orchidopexy } \\
\hline & & 26 days & 54 days & 81 days & 109 days \\
\hline \multicolumn{6}{|l|}{$\mathrm{Wt}$ of non-ligated testis (g) } \\
\hline Control & $1.65 \pm 0.05$ & $\begin{array}{c}1.74 \pm 0.04 \\
(10)\end{array}$ & $\begin{array}{c}1.77 \pm 0.05 \\
(10)\end{array}$ & $\begin{array}{c}1.72 \pm 0.05 \\
(10)\end{array}$ & $\begin{array}{c}1.77 \pm 0.03 \\
(10)\end{array}$ \\
\hline Operated & $0 \cdot 61 \pm 0.02^{b}$ & $\begin{array}{c}0.73 \pm 0.03^{\mathrm{b}} \\
(13)\end{array}$ & $\begin{array}{c}0.84 \pm 0.04^{\mathrm{bc}} \\
(10)\end{array}$ & $\begin{array}{c}0.88 \pm 0.05^{\mathrm{bd}} \\
(13)\end{array}$ & $\begin{array}{c}0.78 \pm 0.04^{\mathrm{bc}} \\
(13)\end{array}$ \\
\hline \multicolumn{6}{|l|}{ Epididymal wt (g) } \\
\hline Control & $0.57 \frac{ \pm 0.03}{(5)}$ & $0.59 \pm \frac{ \pm 0.02}{(5)}$ & $0 \cdot 64 \underset{(5)}{ \pm} 0.03$ & $0.62 \pm \frac{0.03}{(5)}$ & $0.62 \pm 0.03$ \\
\hline Operated & $0 \cdot 33 \pm 0 \cdot 01^{b}$ & $0 \cdot 35 \pm 0.01^{b}$ & $\begin{array}{c}0 \cdot 31 \pm 0.02^{b} \\
(10)\end{array}$ & $0 \cdot 36 \pm 0.02^{b}$ & $0 \cdot 38 \pm 0.02^{b}$ \\
\hline \multicolumn{6}{|l|}{ Fluid production $(\mathrm{g} / 16 \mathrm{~h})$} \\
\hline Control & $0.41 \pm \frac{0.03}{(5)}$ & $0.36 \underset{(5)}{ \pm 0.02}$ & $0.44 \underset{(5)}{ \pm 0.04}$ & $0.41 \pm 0.03$ & $0 \cdot 40 \pm 0.03$ \\
\hline Operated & $0 \cdot 19 \pm 0 \cdot 05^{a}$ & $0.13 \pm 0.03^{b}$ & $0 \cdot 12 \pm 0.04^{b}$ & $0.09 \pm 0.04^{b}$ & $0 \cdot 15 \pm 0.04^{b}$ \\
\hline \multicolumn{6}{|l|}{ Serum testosterone $(\mathrm{ng} / \mathrm{ml})$} \\
\hline Control & $\begin{array}{c}2 \cdot 3 \pm 0 \cdot 5 \\
(10)\end{array}$ & $\begin{array}{l}2 \cdot 9 \pm 0 \cdot 5 \\
(10)\end{array}$ & $\begin{array}{c}2 \cdot 7 \pm 0 \cdot 7 \\
(10)\end{array}$ & $3 \cdot 2 \pm 0 \cdot 9$ & $\begin{array}{c}1.9 \pm 0.6 \\
(10)\end{array}$ \\
\hline Operated & $\begin{array}{c}3 \cdot 0 \pm 0 \cdot 6 \\
(10)\end{array}$ & $\begin{array}{c}3 \cdot 0 \pm 0 \cdot 2 \\
(13)\end{array}$ & $\begin{array}{c}1 \cdot 9 \pm 0 \cdot 2 \\
(10)\end{array}$ & $\begin{array}{c}1 \cdot 5 \pm 0 \cdot 2 \\
(13)\end{array}$ & $\begin{array}{c}2.95 \pm 0 \cdot 3 \\
(13)\end{array}$ \\
\hline \multicolumn{6}{|l|}{$\begin{array}{l}\text { In-vitro testosterone } \\
\text { production (ng/testis) }\end{array}$} \\
\hline Control basal & $82 \pm \frac{13}{(5)}$ & $53 \pm \frac{6}{(5)}$ & $51 \pm 8$ & $82 \pm \frac{12}{(5)}$ & $77 \pm 9$ \\
\hline —stimulated & $514 \underset{(5)}{ \pm}$ & $283 \pm 50$ & $166 \pm 23$ & $226 \pm 26$ & $181+\frac{ \pm 11}{(5)}$ \\
\hline Operated_-basal & $231 \pm 48^{c}$ & $214 \pm 31^{a}$ & $246 \pm 10^{b}$ & $261 \pm 28^{b}$ & $266 \pm{ }^{(5)}$ \\
\hline -stimulated & $1501 \pm 254^{a}$ & $1584 \pm 211^{b}$ & $1128 \pm 66^{b}$ & $1891 \pm 210^{b}$ & $2096 \pm 269^{b}$ \\
\hline
\end{tabular}

Values are mean \pm s.e.m. for the no. of observations in parentheses. Values significantly different from control value: ${ }^{a} P<0.01 ;{ }^{b} P<0.001(t$ test $)$. Values significantly different from that after 10 days of cryptorchidism: ${ }^{c} P<0.05 ; \mathrm{d} P<0.01$ (Duncan's test). 
hyper-responsive to hCG stimulation in vitro after 4 weeks of cryptorchidism (results not shown) and were not different from the results after 10 days of cryptorchidism (see below). After orchidopexy, no return to normal was noted in any of the features described above (results not shown).

\section{Experiment 2: orchidopexy after 10 days of cryptorchidism}

There was a significant decrease in testicular weight to $37 \%$ of control in 10-day cryptorchid rats (Table 2). After orchidopexy a small but significant increase occurred, testicular weight reaching $48 \%$ of control value 81 days after orchidopexy (Table 2). However, epididymal weight which had decreased to $58 \%$ of control after 10 days of cryptorchidism, did not increase significantly (Table 2 ).

Histology. In the cryptorchid rats there was a reduction in seminiferous tubule diameter and a widening of the intertubular space. In the majority of the tubules the epithelium consisted of Sertoli cells and spermatogonia which were reduced in numbers. In a few tubules remnants of mature spermatids persisted at the luminal border of the Sertoli cells (P1. 1, Fig. 1). By 6 months after orchidopexy there was patchy recovery of spermatogenesis. Some tubules showed active spermatogenesis whereas others were lined by Sertoli cells only. A few tubules showed intermediate stages of recovery in which all stages of spermatogenesis could be identified but there was a decrease in the numbers of germ cells within the epithelium (Pl. 1, Fig. 2).

Seminiferous tubule fluid production. After 10 days of cryptorchidism tubule fluid production was significantly reduced to $46 \%$ of the control rat values. Despite orchidopexy, fluid production did not recover, mean levels ranging between 22 and $37 \%$ of control (Table 2 ).

$A B P$ content and production. The ABP content of the non-ligated testis 10 days after cryptorchidism was significantly decreased $(P<0.01)$ and returned to control levels 26 days after orchidopexy (Text-fig. 1). The ABP content of the ligated testis was also significantly reduced $(P<$ $0.01)$ after 10 days of cryptorchidism, and orchidopexy did not result in a significant change until 54 days later. At this time and at 109 days after orchidopexy the ABP content of ligated testes was significantly greater than that at 10 days after cryptorchidism but was still significantly less than in the control animals (Text-fig. 1). The difference in the ABP content of the ligated and non-ligated

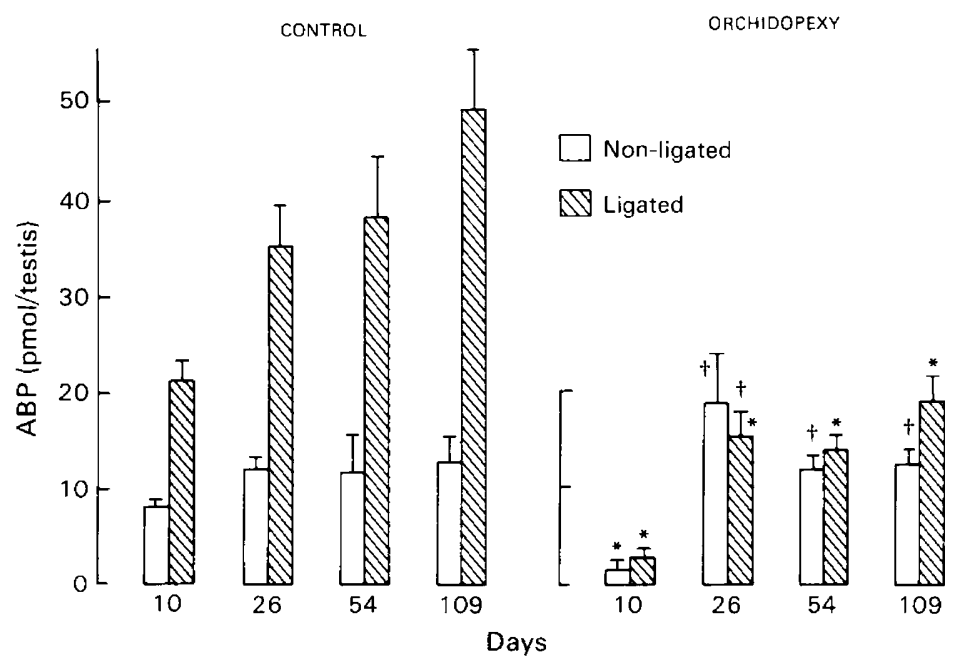

Text-fig. 1. The effect of 10 days of cryptorchidism and subsequent orchidopexy on the testicular ABP content in non-ligated and ligated testes after efferent duct ligation. The ABP production rate is represented by the difference between the ABP content of the ligated and non-ligated testes. Values represent mean \pm s.e.m. for 35 rats per group. ${ }^{*} P<0.01$ compared to control rat values; $\dagger P<0.01$ compared to cryptorchid state at 10 days. 
testes, which provides an index of ABP production (Text-fig. 1), was undetectable after 10 days of cryptorchidism and did not recover until 54 days after orchidopexy when it was still significantly less than normal.

Serum testosterone and in-vitro testosterone production. No significant change was found in serum testosterone levels throughout the experiment (Table 3). However, both basal and stimulated production was increased after 10 days of cryptorchidism. There was no further change, even by 109 days after orchidopexy.

Table 3. Comparison of a number of indicators in control rats and groups of rats that were fertile or infertile 6 months after orchidopexy which was preceded by a 10 day period of cryptorchidism

\begin{tabular}{|c|c|c|c|}
\hline & Control & Infertile & Fertile \\
\hline Total testicular wt $(\mathrm{g})$ & $1.83 \pm 0.09$ & $0.90 \pm 0.08^{\mathrm{c}}$ & $1 \cdot 16 \pm 0 \cdot 20^{\mathrm{b}}$ \\
\hline Decapsulated testicular wt (g) & $1.77 \pm 0.09$ & $0.41 \pm 0.02^{c}$ & $0.94 \pm 0.23^{\mathrm{bc}}$ \\
\hline Epididymal wt (g) & $0.65 \pm 0.02$ & $0.40 \pm 0.01^{\mathrm{c}}$ & $0.53 \pm 0.07$ \\
\hline Testicular ABP content (pmol) & $9 \cdot 6 \pm 1 \cdot 4$ & $9 \cdot 3 \pm 1 \cdot 8$ & $11 \cdot 1 \pm 0.6$ \\
\hline Epididymal ABP content (pmol) & $33 \cdot 8 \pm 3 \cdot 6$ & N.D. & $4 \cdot 8 \pm 1 \cdot 2^{\mathrm{cd}}$ \\
\hline Binding of ${ }^{125}$-labelled FSH (pg/testis) & $73 \pm 16.6$ & $38 \pm 8 \cdot 7^{\mathrm{ac}}$ & $89 \pm 12 \cdot 9$ \\
\hline Serum testosterone $(\mathrm{ng} / \mathrm{ml})$ & $2 \cdot 2 \pm 0 \cdot 4$ & $3.4 \pm 0.8$ & $1 \cdot 7 \pm 0.4$ \\
\hline \multicolumn{4}{|l|}{$\begin{array}{l}\text { In-vitro testosterone production } \\
\text { (ng/testis } / 4 \mathrm{~h})\end{array}$} \\
\hline Basal & $95 \cdot 2 \pm 17$ & $890 \pm 226^{b}$ & $216 \cdot 8+51^{\text {ad }}$ \\
\hline Stimulated & $467 \cdot 2 \pm 103$ & $5897 \pm 800^{c}$ & $2086 \pm 594^{\text {ad }}$ \\
\hline Incremental & $372 \pm 86$ & $5007 \pm 690^{\circ}$ & $1870 \pm 569^{\mathrm{ac}}$ \\
\hline Binding of ${ }^{125} \mathrm{I}$-labelled hCG (ng/testis) & $10 \cdot 7 \pm 1 \cdot 0$ & $3 \cdot 8 \pm 1 \cdot 0^{\mathrm{c}}$ & $5 \cdot 9 \pm 1 \cdot 2^{\mathrm{a}}$ \\
\hline Serum FSH (ng/ml) & $336 \pm 70$ & $799 \pm 156^{a}$ & $409 \pm 51^{d}$ \\
\hline Serum LH $(\mathrm{ng} / \mathrm{ml})$ & $0.60 \pm 0.05$ & $3.74 \pm 0.41^{\mathrm{c}}$ & $0.84 \pm 0.05^{e}$ \\
\hline
\end{tabular}

Values are mean \pm s.e.m. for 5 rats/group. N.D., not detectable.

Significantly different from control value: ${ }^{a} P<0.05 ;{ }^{b} P<0.02$; ${ }^{\text {}} P<0.001$.

Significantly different from value for infertile rats: ${ }^{\mathrm{d} P}<0.05 ;{ }^{\mathrm{e}} P<0.01$.

Serum FSH and LH concentrations. Values of both hormones were significantly elevated after 10 days of cryptorchidism but remained elevated after orchidopexy (Text-fig. 2).

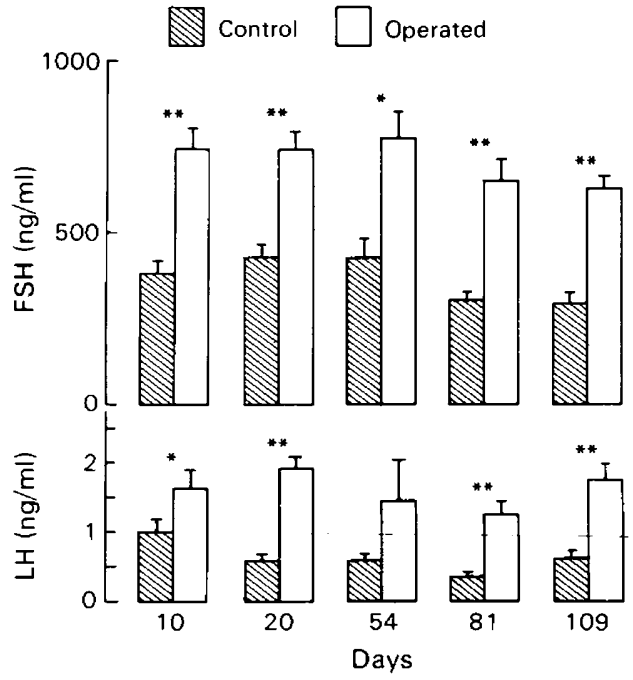

Text-fig. 2. The effect of 10 days of cryptorchidism and subsequent orchidopexy on serum FSH and LH levels. Values are mean \pm s.e.m. for 9-13 rats per group. Compared with control values: ${ }^{*} P<0.05,{ }^{* *} P<0.001$. 
PLATE 1
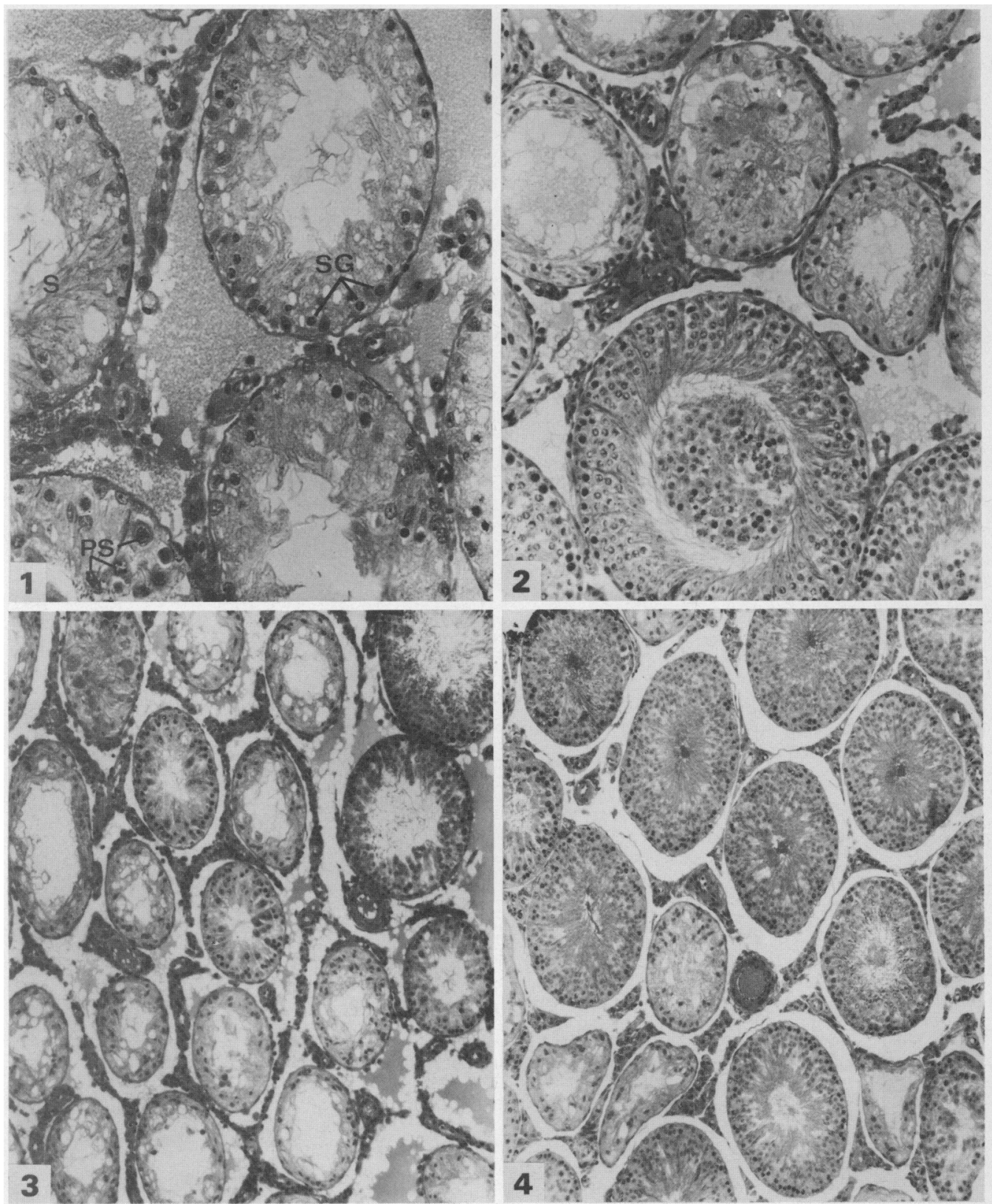

Fig. 1. Testicular architecture after 10 days of cryptorchidism. Note spermatogonia (SG), primary spermatocytes (PS), residual sperm tails $(S)$ and Sertoli cells. $\times 145$.

Fig. 2. Section showing the state of the testis 6 months after a period of 10 days of cryptochidism. Note patchy recovery of spermatogenesis. $\times 145$

Fig. 3. Representative section of the testis from an infertile rat in Exp. 3. Note the very few tubules with recovery of spermatogenesis. $\times 80$.

Fig. 4. Representative section of a testis from a rat from the fertile group in Exp. 3. Note the greater percentage of tubules with spermatogenesis. $\times 80$. 
Fertility. After 10 days of cryptorchidism all rats were sterile whereas $7 / 10$ females mated to control rats were pregnant with $10.3 \pm 0.5 \mathrm{embryos} /$ pregnant female. After orchidopexy for 27, 54, 81 and 109 days the number of pregnant females and the number of embryos/pregnant female were $0 / 10,0 / 10,3 / 10$ and $8.3 \pm 1.8$ and $4 / 10$ and $4.5 \pm 1 \cdot 2$, respectively. The equivalent values for the control rats at these times were $9 / 10$ and $13.3 \pm 0.8,9 / 10$ and $11.9 \pm 0.9,9 / 10$ and $10 \cdot 1 \pm 0.9$ and $10 / 10$ and $11.6 \pm 0.4$ respectively.

Experiment 3: comparison of testicular function in control rats and in infertile and fertile rats 180 days after orchidopexy

Testis and epididymal weight. Total testicular weight was significantly lower in fertile and infertile rats (51 and $37 \%$ of control; respectively; Table 3 ). No significant difference was noted between the infertile and fertile groups. However, after decapsulation, which effectively drains the extratubular fluid, there was a $23 \%$ reduction in testicular weight in the fertile rats but a $53 \%$ weight reduction in the infertile rats (Table 3). Epididymal weight in the infertile rats was significantly lower than that of controls but there was no difference between the weights of the fertile rats and controls (Table 3).

Histology. In the infertile rats, $75-80 \%$ of the seminiferous tubules were reduced in diameter and many were lined by Sertoli cells only. A few tubules showed active spermatogenesis (10-15\%) and others showed partial recovery (Pl. 1, Fig. 3). In the fertile rats the proportion of tubules with active spermatogenesis was greater, with complete restoration of the epithelium (Pl. 1, Fig. 4). However, in $25-30 \%$ of tubules there was no recovery and only Sertoli cells lined the epithelium. In $10-15 \%$ of tubules recovery of spermatogenesis was only partial.

$A B P$ content of testis and epididymis. No significant differences were found in the ABP content of the testes in the three groups (Table 3). However epididymal ABP was undetectable in the infertile rats and the levels in the fertile rats, although higher than in the infertile rats, were significantly lower than those in controls (Table 3).

Binding of ${ }^{125}$ I-labelled FSH to testis homogenates. Values for the infertile rats were significantly lower $(P<0.05)$ than those of controls $(52 \%$, Table 3$)$. No significant difference was found between the control and the fertile rats (Table 3 ).

Serum testosterone and in-vitro testosterone production. No significant differences were found between the groups for serum testosterone values (Table 3). Basal in-vitro testosterone production was 9-10-fold greater in the infertile group and only 2-3 times higher in the fertile group when compared to control levels (Table 3). The hCG-stimulated level and the incremental rise of testosterone was significantly greater in the infertile rats than in the fertile and control rats (Table 3). Although less than in the infertile group, the stimulated and incremental testosterone production in the fertile group was significantly greater than $(P<0.05)$ those of the controls (Table 3).

Binding of ${ }^{125}$ I-labelled $h C G$ to testis homogenates. There was a significantly lower binding to homogenates of testes from the infertile and fertile rats when compared to controls (Table 3). Binding was greater in the fertile than infertile rats but the difference did not reach significance.

Serum FSH and LH concentrations. Serum FSH and LH values were significantly elevated in the infertile rats when compared to those levels in control or fertile rats, which did not differ (Table 3). No significant difference was found between the FSH and LH concentrations in the fertile and control groups.

\section{Discussion}

This study confirms that the spermatogenic disruption that accompanies the induction of cryptorchidism is accompanied by changes in Sertoli cell and Leydig cell function (Hagenäs \& Ritzén, 1976; Kerr et al., 1979a, b; Jégou et al., 1983). However, this study clearly demonstrates 
that restoration of the scrotal position of the testes by orchidopexy is not accompanied by immediate reversal of the changes in Sertoli cell and Leydig cell function, suggesting that the Sertoli cell and Leydig cell changes may not be related to the thermal change associated with cryptorchidism but to the associated spermatogenic damage. This concept has been confirmed for the Leydig cell changes since identical alterations have been shown following spermatogenic damage induced by fetal irradiation, Vitamin A deficiency, hydroxyurea treatment or efferent duct ligation (Rich \& de Kretser, 1977, 1979; Rich, Kerr \& de Kretser, 1979; Risbridger et al., 1981b).

The concept that the changes in Sertoli cell and Leydig cell function may be associated with spermatogenic damage is also supported by the results of Exp. 3, which clearly show that the indicators of Sertoli cell and Leydig cell function returned to normal or towards normality in the rats with sufficient spermatogenic recovery to induce fertility but remained essentially unchanged in the infertile rats. Absolute return to normality was not found even in the fertile rats but recovery of spermatogenesis was obviously not complete since testicular weight represented only $51 \%$ of the value of control animals.

It was surprising that spermatogenesis did not recover when orchidopexy was performed at 10 or 28 days after the induction of cryptorchidism since Nelson (1951) reported excellent recovery when cryptorchidism was reversed after 28 days. However, our results are in accord with those of Hayashi \& Cedenho (1980) who noted that bilateral cryptorchidism for longer than 5-7 days produced irreversible sterility in most of the rats. The results of these two studies suggest that the failure of spermatogenic recovery after prolonged cryptorchidism is due to a marked attrition of spermatogonial numbers. The age at which cryptorchidism is performed also affects the potential for recovery since Karpe, Plöen, Hagenäs \& Ritzén (1981) showed that recovery of testicular function in rats made cryptorchid at 17 days of age can only be complete if orchidopexy is performed early during sexual maturation.

In Exp. 2, the ABP content of the unligated testis returned to control levels after 26 days but ABP production only partially recovered after 54 days. The failure of ABP to accumulate to any great extent after efferent duct ligation is probably related to the absence of any recovery in terms of fluid production. This view is consistent with the observation that the epididymal ABP content in the infertile rats in Exp. 3 was undetectable in the presence of a normal ABP content of the testis.

The failure of FSH levels to return to normal in those rats in which spermatogenesis did not recover after orchidopexy is of interest since it has been shown that inhibin production decreases after cryptorchidism (Au, Robertson \& de Kretser, 1983). It is likely that the elevated FSH levels are an indirect reflection of diminished inhibin production by Sertoli cells since testosterone levels in this experiment did not alter. The normal FSH levels in the fertile rats in Exp. 3 support this view because these rats showed recovered Sertoli cell function as assessed by ABP content, partial return of epididymal ABP and normal binding of ${ }^{125}$ I-labelled FSH to testicular tissue.

In the rats in which fertility was restored by orchidopexy in Exp. 3, hyper-responsiveness of Leydig cells to hCG stimulation persisted although to a lesser degree than in the infertile rats. This finding would be consistent with the view that normal spermatogenesis and normal Sertoli cell function must be restored before reversal of the Leydig cell changes. Although we had hoped that a distinct temporal sequence of events could be detected after orchidopexy to provide definitive evidence for this concept, the failure of the testes to recover in most animals interfered with this aim. There is, however, increasing evidence to suggest that the germ cells, Sertoli cells and Leydig cells exhibit a complex interaction. It has been demonstrated that the function of the Sertoli cell varies with the stage of the seminiferous cycle and the presence of germ cell types (Ritzen, Hansson \& French, 1981 ; Galdieri, Zani \& Stefanini, 1981). Furthermore, Bergh (1982) has shown that the size of the Leydig cells may also be influenced by the stage of the cycle of the seminiferous epithelium in the surrounding tubules. All of this evidence supports the hypothesis that the seminiferous tubules, by secretions emanating from the germ cells or Sertoli cells, are capable of modifying Leydig cell structure and function (Aoki \& Fawcett, 1978; Kerr et al., 1979a; de Kretser, 1982). 


\section{References}

Aoki, A. \& Fawcett, D.W. (1978) Is there a local feedback from the seminiferous tubules affecting activity of the Leydig cell? Biol. Reprod. 19, 144-158.

Au, C.L., Robertson, D.M. \& de Kretser, D.M. (1983) Invitro bioassay of inhibin in testes of normal and cryptorchid rats. Endocrinology 112, 239-244.

Bergh, A. (1982) Local differences in Leydig cell morphology in the adult rat testis: evidence for a local control of Leydig cells by adjacent seminiferous tubules. Int. J. Androl. 5, 325-330.

de Kretser, D.M. (1982) Sertoli cell-Leydig cell interaction in the regulation of testicular function. Int. $J$. Androl., Suppl. 5, 11-17.

de Kretser, D.M., Sharpe, R.M. \& Swanston, I.A. (1979) Alterations in steroidogenesis and human chorionic gonadotropin binding in the cryptorchid rat testis. Endocrinology 105, 135-138.

Galdieri, M., Zani, B. \& Stefanini, M. (1981) Effect of the association with germ cells on the secretory activities of Sertoli cells in in vitro cultures. In Oligozoospermia, Recent Progress in Andrology, pp. 95-103. Ed. G. Frajese. Raven Press, New York.

Hagenäs, L. \& Ritzén, E.M. (1976) Impaired Sertoli cell function in experimental cryptorchidism. Molec. Cell. Endocr. 4, 25-35.

Hayashi, H. \& Cedenho, A.P. (1980) Fertilizing capacity of the cryptorchid rat. J. Reprod. Fert. 59, 79-82.

Jégou, B., Risbridger, G.P. \& de Kretser, D.M. (1983) Effects of experimental cryptorchidism on testicular function in adult rats. $J$. Androl. 4, 88-94.

Karpe, B., Plöen, L., Hagenäs, L. \& Ritzén, E.M. (1981) Recovery of testicular function after surgical treatment of experimental cryptorchidism in the rat. Int. J. Androl. 4, 145-160.

Kerr, J.B., Rich, K.A. \& de Kretser, D.M. (1979a) Effects of experimental cryptorchidism on the ultrastructure and function of the Sertoli cell and peritubular tissue of the rat testis. Biol. Reprod. 21, 823-839.

Kerr, J.B., Rich, K.A. \& de Kretser, D.M. (1979b) Alterations of the fine structure and androgen secretion of the interstitial cells in the experimentally cryptorchid rat testis. Biol. Reprod. 20, 409-422.

Lee, V.W.K., de Kretser, D.M., Hudson, B. \& Wang, C. (1975) Variations in serum FSH, LH and testosterone levels in male rats from birth to sexual maturity. $J$. Reprod. Fert. 42, 121-126.

Moore, C.R. (1924) Properties of the gonads as controllers of somatic and psychical characteristics. VI. Testicular reactions in experimental cryptorchidism. Am. J. Anat. 34, 269-316.
Nelson, W.O. (1951) Mammalian spermatogenesis: effect of experimental cryptorchidism in the rat and non descent of the testis in man. Recent Prog. Horm. Res, 6, 29-56.

Rich, K.A. \& de Kretser, D.M. (1977) Effect of differing degrees of destruction of the rat seminiferous epithelium on levels of serum follicle stimulating hormone and androgen binding protein. Endocrinology 101, 959-968.

Rich, K.A. \& de Kretser, D.M. (1979) Effect of fetal irradiation on testicular receptors and testosterone response to gonadotrophin stimulation in adult rats. Int. J. Androl. 2, 343-352.

Rich, K.A., Kerr, J.B. \& de Kretser, D.M. (1979) Evidence for Leydig cell dysfunction in rats with seminiferous tubule damage. Molec. cell. Endocr. 13, 123-135.

Risbridger, G.P., Kerr, J.B. \& de Kretser, D.M. (1981a) Evaluation of Leydig cell function and gonadotrophin binding in unilateral and bilateral cryptorchidism: evidence for local control of Leydig cell function by the seminiferous tubule. Biol. Reprod. 24, $534-540$.

Risbridger, G.P., Kerr, J.B., Peake, R.A. \& de Kretser, D.M. (1981 b) An assessment of Leydig cell function after bilateral or unilateral efferent duct ligation: further evidence for local control of Leydig cell function. Endocrinology 109, 1234-1241.

Risbridger, G.P., Kerr, J.B., Peake, R.A., Rich K.A. \& de Kretser, D.M. (1981c) Temporal changes in rat Leydig cell function after the induction of bilateral cryptorchidism. J. Reprod. Fert. 63, 415-423.

Risbridger, G.P., Robertson, D.M. \& de Kretser, D.M. (1982) The effects of chronic human chorionic gonadotropin treatment on Leydig cell function. Endocrinology 110, 138-145.

Ritzén, E.M., French, F.S., Weddington, S.C., Nayfeh, S.N. \& Hansson, V. (1974) Steroid binding in polyacrylamide gels: quantitation at steady state conditions. J. biol. Chem. 249, 6597-6604.

Ritzén, E.M., Hansson V. \& French F.S. (1981) The Sertoli cell. In The Testis, pp. 171-194. Eds H. G. Burger \& D. M. de Kretser. Raven Press, New York.

Sharpe, R.M. \& Fraser, H.M. (1980) Inhibition of maturational changes in Leydig cell function by treatment of rats with an agonist of LH-RH. J. Reprod. Fert. 60, 359-368.

Smith, G. (1962) The effects of ligation of the vasa efferentia and vasectomy on testicular function in the adult rat. $J$. Endocr. 23, 385-399. 